\title{
NOTAS SOBRE A FEITURA DE UM NOVO ESTADO NA AMAZÔNIA PARAENSE: AFETOS E AFETAÇ̃̃ES EM MOBILIZAÇÕES SOCIAIS PELO TAPAJÓS
}

Telma de Sousa Bemerguy (D) 


\section{RESUMO}

A partir dos resultados de minha pesquisa de mestrado junto a atores envolvidos na mobilização pela criação do estado do Tapajós, neste artigo irei apresentar ações/justificações mobilizadas por meus interlocutores para demonstrar/produzir/agenciar afetos em torno da "causa" no município de Santarém, localidade que mais apoiou o projeto no contexto do plebiscito realizado no estado do Pará em 2011. Pretendo demonstrar como a "causa" pôde crescer a partir de uma captura exitosa de uma série de afetos difusos relacionados ao termo "Tapajós" e apresentar algumas considerações sobre o lugar ocupado pela linguagem dos afetos no processo de produção de adesão a projetos políticos controversos.

Palavras-chave: afetos; mobilizações sociais; Amazônia

\section{NOTES ON THE MAKING OF A} NEW STATE IN THE PARÁ AMAZON: AFFECTS AND AFFECTIONS ON SOCIAL MOBILIZATIONS BY TAPAJÓS

\section{ABSTRACT}

Based on the results of my master's research with actors of the mobilization for the creation of the Tapajós State, in this article I will describe a few actions/ justifications mobilized by my interlocutors to demonstrate/produce/agency affections around the "cause" in the city of Santarém, the location that most supported the project in the context of the plebiscite held in 2011. My intentions are to demonstrate how the "cause" could grow from a successful capture of a series of diffuse affects related to the term "Tapajós" was crucial for the growing of the "cause" and to present some considerations about how the language of the affects actuate in the process of producing adhesion to controversial political projects.

Keywords: affects; social mobilizations; Amazon.

\section{NOTAS SOBRE LA CREACIÓN DE UN NUEVO ESTADO EN LA AMAZONIA PARAENSE: AFECTOS Y AFECTACIONES EN MOVILIZACIONES SOCIALES POR EL TAPAJÓS}

A partir de los resultados de mi investigación de maestría junto a actores involucrados en la movilización por la creación del Estado de Tapajós, en este artículo presentaré acciones/ justificaciones movilizadas por mis interlocutores para demostrar/producir/ agenciar afectos en torno a la "causa" en el municipio de Santarém, localidad que más apoyó el proyecto en el contexto del plebiscito realizado en 2011. Pretendo demostrar cómo la "causa" pudo crecer a partir de una captura exitosa de una serie de afectos difusos relacionados al término "Tapajós" y presentar algunas consideraciones sobre el lugar ocupado por el lenguaje de los afectos en el proceso de producción de adhesiones a proyectos políticos controversiales.

Palabras clave: afectos; movilización social; Amazonia 


\section{INTRODUÇÃO}

No dia 11 de dezembro de 2011, o eleitor paraense foi às urnas para responder a duas perguntas: "Você é a favor da criação do estado do Tapajós?" e "Você é a favor da criação do estado do Carajás?”. Aqueles que desejassem votar SIM deveriam digitar o número 77 e aqueles que optassem pelo NÃO, o número 55. No dia 13 de setembro de 2011, teve início o período de campanha, através da distribuição de panfletos, uso de cartazes e de alto-falantes, bem como da realização de comícios. A partir do dia 11 de novembro de 2011, 30 do Tapajós e 66,60\% de votos contrários à criação do Carajás. No entanto, os índices de aprovação ao projeto somente nas áreas que demandavam a emancipação foram bastante elevados, sendo superiores a $90 \%$, tanto no Tapajós quanto no Carajás. Santarém foi o município em que a população se manifestou como mais favorável à divisão do estado, onde 98,63\% dos votantes disseram sim à criação do Tapajós. O município possui cerca de 300 mil habitantes e é o terceiro mais populoso dos 144 que compõem o estado do Pará. Sua sede político-administrativa fica localizada dias antes da realização da consulta, começaram as campanhas radiofônicas e televisivas. $\mathrm{O}$ projeto de plebiscito aprovado previa que o estado do Tapajós (Figura 1) seria composto por 27 municípios e que o estado, se criado, corresponderia a $58 \%$ da área do atual estado do Pará e a $20 \%$ de sua população total. Dizia-se, na região, que a cidade de Santarém seria sua futura capital. Como em um processo similar àqueles que se desenrolam em disputas eleitorais comuns, durando o período de campanha reservado ao plebiscito, "a política invadiu as atividades cotidianas mais díspares" (Heredia \& Palmeira 1995:33), nas conversas de família, na universidade, nos programas de rádio, de TV, nas panfletagens - o debate foi "posto na rua".

A consulta a toda a população paraense resultou em 66,08\% de votos contrários à criação

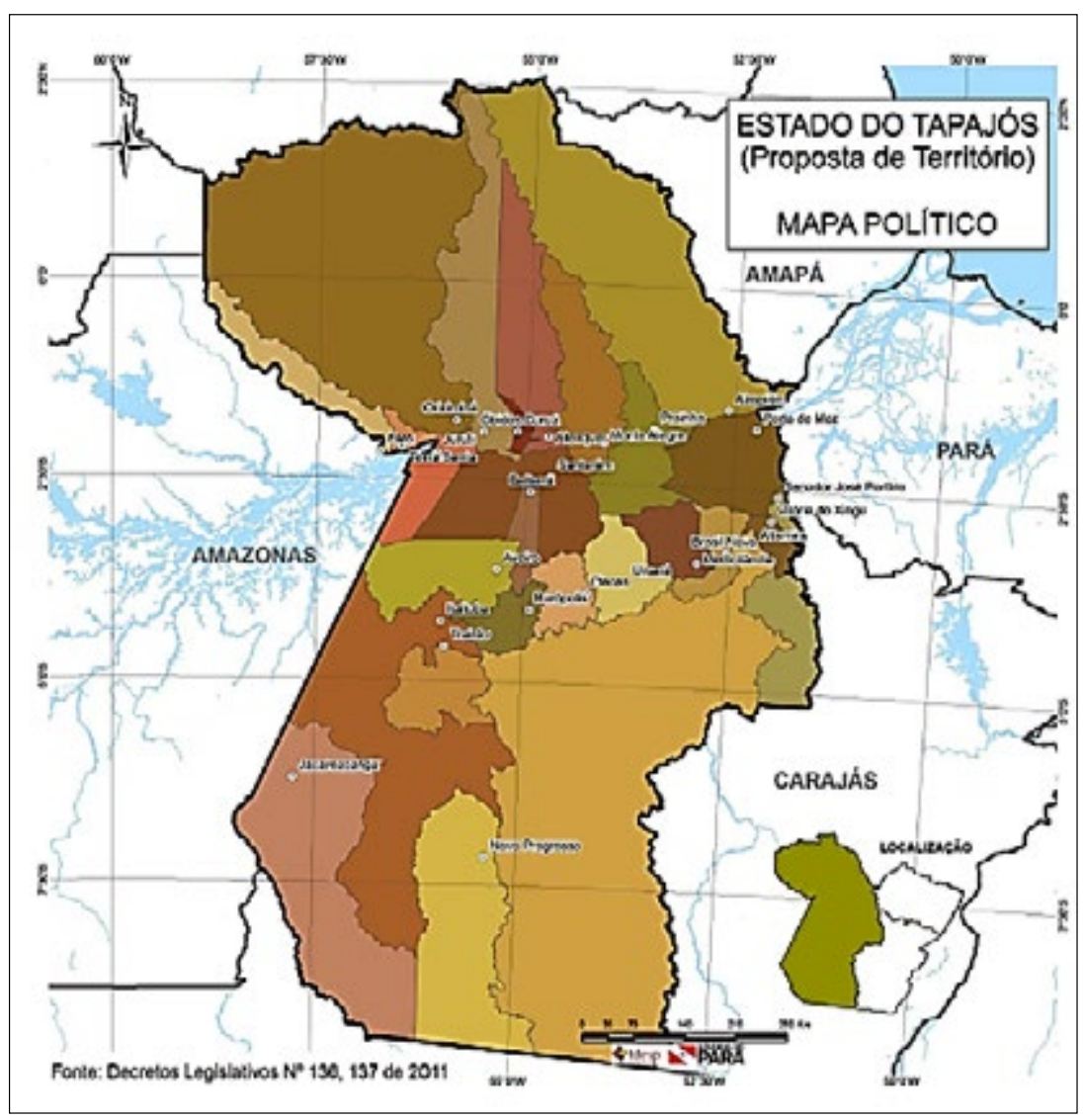

Figura 1 - Área correspondente ao estado do Tapajós no contexto do plebiscito. Fonte: IDESP (2011). 
à margem direita do rio Tapajós, na confluência com o rio Amazonas, rios de cores distintas que se encontram, sem se misturar, na "frente da cidade", produzindo uma paisagem que orgulha os locais e constituindo um referente que muito se entrelaça com os debates pela criação do novo estado. Nasci e residi em Santarém até o início de $2015^{1}$ e ali realizei grande parte da pesquisa que apresentei em minha dissertação de mestrado (Bemerguy 2017), onde busquei descrever como o projeto de criação do estado do Tapajós foi produzido ao longo do tempo enquanto uma "causa justa" (Boltanski 1990), a qual, segundo os militantes que entrevistei, representava uma "bandeira de luta" de toda uma “região" (Bourdieu 1989), o oeste do Pará(Figura 2)². Ao

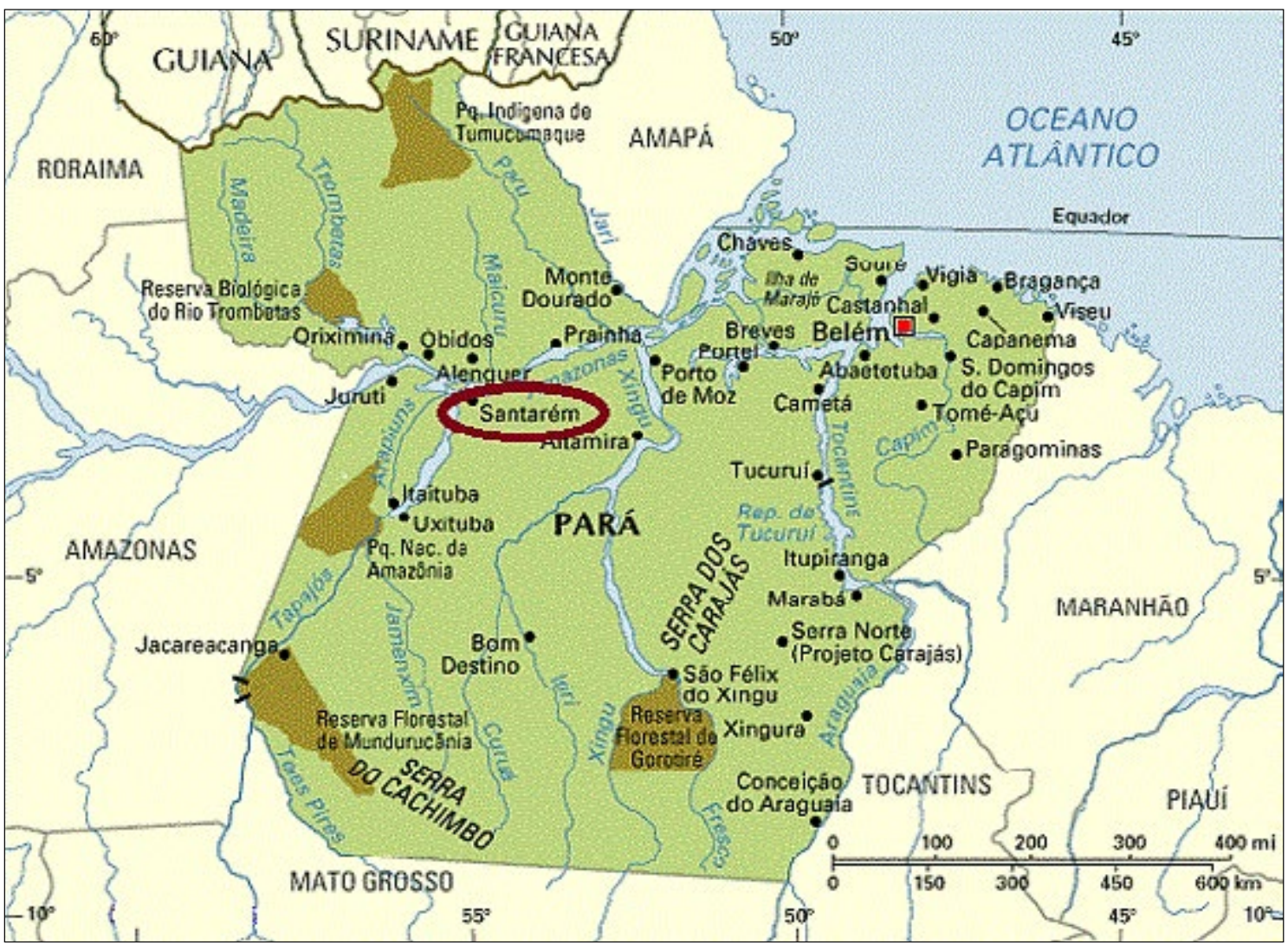

Figura 2 - Local da pesquisa. Fonte: Guianet (2016), adaptado pela autora.

1 Nos limites deste artigo, não aprofundarei a forma como meu pertencimento ao local atravessou o processo de realização da pesquisa. Contudo, acredito que seja importante mencionar que a decisão por refletir analiticamente sobre os afetos mobilizados em torno da luta pela criação do Tapajós foi motivada por questões relacionadas às particularidades de minha inserção etnográfica como "filha da região". Para maiores detalhes sobre o processo de realização da pesquisa nesses termos, ver Bemerguy (2017).

2 O léxico principal de categorias mobilizadas por meus interlocutores para produzir a justeza e a legitimidade da "causa" no sentido trabalhado por Boltanski (1990) será destacado ao longo do texto, através do uso do itálico. O uso 
longo de seis viagens de retorno ao Pará, entre julho de 2015 e setembro de 2016, realizei entrevistas com indivíduos envolvidos de diferentes maneiras no debate pela criação do novo estado: professores universitários, jornalistas, radialistas, historiadores, clérigos, lideranças de movimentos sociais, lideranças de partido político e gestores de instituições. A maioria era residente da cidade de Santarém e esteve ligada à campanha pelo voto SIM no plebiscito realizado em 2011.

Ao longo da pesquisa, os relatos de meus interlocutores sobre seu trabalho de militância a favor do projeto tornaram-se um ponto de partida para a realização de uma etnografia sobre o processo de criação de um estado - nesse caso, na escala de uma unidade federativa -, onde busquei descrever os procedimentos burocráticos, as negociações e as atividades de mobilização conduzidas em diversos municípios da região oeste do Pará durante o cotidiano dos anos que se passaram entre o momento que o debate começou a ganhar força e a "conquista da realização do plebiscito". Etnografando "para cima” (Nader 1972) ${ }^{3}$ e "para baixo", busquei explorar os diversos espaços e temporalidades das ações realizadas para que a consulta se tornasse realidade, de modo que pudesse descrever como se conquistou apoio ao projeto no Congresso Nacional e como foi produzida a crença na justeza da luta pela criação do estado do Tapajós tanto entre os militantes dirigentes do movimento quanto entre a população da região.

Essa etnografia do processo em diversas escalas me permitiu observar que a multiplicidade de atores que precisavam ser favoráveis ao projeto para que o estado do Tapajós pudesse acontecer foi determinante para que, principalmente durante o processo de campanha para o plebiscito realizado em 2011, ocorresse uma "controvérsia" e um confronto entre expectativas "incompatíveis" (Boltanski \& Thévenot 1999:359) sobre o que a concretização do projeto representaria para a região. Desde um quadro de análise inspirado em trabalhos produzidos no marco da teoria pragmática francesa ${ }^{4} \mathrm{e}$ especialmente na sociologia da crítica de Boltanski, tratei as elaborações de

das aspas está reservado a referências bibliográficas e a citações de trechos das entrevistas. É importante destacar que alguns termos utilizados por meus interlocutores também serão referenciados como categorias analíticas, por isso termos iguais poderão estar destacados em aspas ou em itálico, dependendo do contexto.

3 A expressão cunhada por Nader (1972) tornou-se uma forma corrente de referenciar trabalhos antropológicos sobre grupos ou sujeitos em posições hierárquicas superiores ou simétricas a do pesquisador e sobre grupos que ocupam a ponta de cima das relações de poder que regulam a vida das minorias, usualmente estudadas pela antropologia, tais como os agentes de Estado e as elites econômicas. Para uma discussão sobre o lugar desse debate na produção antropológica brasileira, ver Castilho et al. (2017).

4 A abordagem pragmatista consiste em um quadro de análise centrado nas linguagens das justificações e das denúncias, apresentadas por diferentes atores na "arena pública”, o qual nos provoca a observar como os "problemas públicos" e as "causas coletivas" não são algo dado, mas situações que são produzidas como tal a partir da interação e do embate 
meus interlocutores como "operações críticas", para que, assim, pudesse descrever desde sua perspectiva quais argumentos tiveram força para conseguir agregar indivíduos com perfis e expectativas díspares em torno de um projeto comum e indicar quais linguagens foram mobilizadas para "fazer a causa crescer", apesar das "incompatibilidades" entre os muitos sins ao estado do Tapajós. A partir dessa proposta analítica, ao fim, pude apresentar algumas considerações sobre como teria sido produzido um "acordo" - uma "quase unanimidade" - em torno da proposta na região que pleiteava se separar para dar origem ao novo estado. Neste artigo, apresento uma das dimensões exploradas para compreender essa enorme adesão ao projeto.

Provocada por falas "emocionadas" acerca do sentimento que motivava a luta, no decorrer da pesquisa, observei que, para compreender a complexidade do projeto e da militância pela criação do estado do Tapajós, seria fundamental incorporar os afetos em minha análise sobre as linguagens que compunham a mobilização. Nesse sentido, entendendo que a atenção ao "redemoinho de paixões que compõem a vida política" pode contribuir para adensar análises sobre mobilizações sociais (Goodwin et al. 2001), neste artigo irei apresentar as ações/justificações mobilizadas por meus interlocutores para demonstrar/produzir/ agenciar afetos em torno da causa no município de Santarém, localidade que mais apoiou o projeto. Assim, buscarei descrever como a mobilização social a favor da criação do novo estado pôde crescer a partir da captura exitosa de uma série de afetos difusos relacionados ao termo Tapajós.

Para tanto, de modo a localizar o lugar ocupado pelos afetos na produção do projeto enquanto uma “causa justa”, primeiramente será necessário recuperar a forma particular como os militantes dirigentes do movimento pela criação do estado do Tapajós significavam a relação da causa com a "política" ponto central para compreender a "controvérsia"

entre os sujeitos. Desde esse quadro de análise, descrever os termos desse embate e as elaborações apresentadas para se apoiar ou não uma denúncia de uma situação apresentada como injusta é fundamental para compreender como determinadas situações de desacordo podem se desdobrar em "causas" políticas. Sobre este debate, ver Boltanski (1990), Cefaï (2009) e Corrêa \& Dias (2016).

5 Trata-se de uma perspectiva de análise que assume que a capacidade de reflexão crítica não é um atributo exclusivo do pesquisador, a qual demarca meu desejo de afastar-me - na medida do possível - da posição assimétrica do pesquisador que busca revelar os "motivos ocultos" que alimentam as decisões dos sujeitos, e que não se permite ouvir e entender, de fato, os caminhos argumentativos percorridos para se chegar a uma determinada posição política. Sobre este ponto, ver Madariaga \& Galleguillos (2013).

6 Minhas reflexões estão marcadas pelo interesse em compreender e descrever a política na chave de uma "antropologia da política", abordagem que procurou criar um contraponto a análises que partiam de pressupostos de como a política deveria ser, privilegiando, assim, uma descrição etnográfica da política a partir das práticas, das ações e das categorias mobilizadas pelos interlocutores para significarem suas experiências da/com a política. Para maiores detalhes sobre 
em torno do projeto. Esse exercício me permitirá explorar como os afetos funcionavam ora como uma realidade incontestável à qual se podia recorrer para legitimar as motivações da militância e as justificações da causa, ora como uma conexão a se produzir para "fazer crescer" a mobilização, ora como uma dimensão que extrapolava os limites do projeto. A partir desse pano de fundo, buscarei apresentar como os efeitos de um tangenciamento possível de afetos de distintas ordens se tornou determinante para a conquista de um apoio maciço à criação do estado do Tapajós no município de Santarém. Por fim, com esse conjunto de questões em mente, destacarei o lugar ocupado pela linguagem dos afetos no processo de produção de uma "causa", indicando como a atenção aos sentimentos e às justificações emocionadas pode contribuir para suscitar novas questões em análises sobre mobilizações sociais na Amazônia.

\section{AS INCOMPATIBILIDADES DA LUTAE A "POLÍTICA" COMO "CONTAMINAÇÃO"}

Para começar a apresentar os termos da disputa em torno da criação do estado do Tapajós, antes de tudo, é importante destacar que tratamos aqui de um projeto que tem como objetivo redesenhar os limites internos do país. Assim, se em determinada escala o caso era produzido pelos atores como uma "luta de um movimento social" ou como um "sonho de uma região", em outra, este se tornava uma matéria de "relevância nacional", "de competência da União"7 - codificado como um debate e uma disputa sobre a forma da "organização políticoadministrativa" do Estado brasileiro. Manter em mente o longo processo de trâmite institucional e os procedimentos burocráticos que precisam ser cumpridos para se criar um novo Estado no país é fundamental para compreender como a "política" se colocava aos militantes do movimento pela criação do estado do Tapajós, e o lugar ocupado por essa relação na montagem da controvérsia em torno do caso.

Conforme a regulamentação prevista na legislação brasileira, para o "sonho" do estado do Tapajós se tornar realidade, primeiro o movimento social deveria conseguir "fazer aprovar" um projeto de decreto legislativo no Congresso Nacional, para

o debate, ver os trabalhos produzidos pelo Núcleo de Antropologia da Política (NUAP), do Programa de Pós-Graduação em Antropologia Social do Museu Nacional: http://nuap.etc.br/publicacoes/colecao-nuap/.

7 No regimento interno do Senado Federal, na parte em que se delimitam as competências da Comissão de Constituição e Justiça, está previsto, no artigo 101, inciso II, que cabe a esta "emitir parecer, quanto ao mérito, sobre as matérias de competência da União, especialmente as seguintes: a) criação de Estado e Territórios, incorporação ou desmembramento de áreas a eles pertencentes” (Brasil 2016).

8 No arquivo disponível no banco de dados do Senado Federal sobre o substitutivo do projeto de decreto legislativo $\mathrm{n}^{\circ}$ 19/1999, que convoca o plebiscito sobre a criação do estado do Tapajós, está indicado no item Assunto: "Administrativo - Organização Político-administrativa do Estado" (Brasil 2011). 
provocar a realização de uma consulta plebiscitária na "área diretamente interessada" na criação do novo estado (Brasil 1988:art. 18, parágrafo 3º). Em seguida, caso a resposta no plebiscito fosse positiva, um deputado ou um senador precisaria apresentar uma proposta de lei complementar para dar início à criação da nova unidade federativa (Brasil 1988:art. 18, parágrafo 3º). Depois, a Casa onde a matéria houvesse sido apresentada ficaria, então, responsável por conduzir audiências junto à Assembleia Legislativa do Estado que seria redesenhado, a qual, por sua vez, ficaria incumbida de apresentar ao Congresso Nacional "os detalhamentos técnicos concernentes aos aspectos administrativos, financeiros, sociais e econômicos da área geopolítica afetada” (Brasil 1998:art 4º, parágrafo $3^{\circ}$ ) e uma opinião fundamentada sobre a viabilidade do novo estado com base nos estudos apresentados. Feito isso, o projeto, então, voltaria à Casa de origem, onde seria avaliado, votado e - se aprovado - encaminhado para avaliação da Casa seguinte: o Senado, caso a lei tivesse sido proposta por um deputado, ou a Câmara, caso tivesse sido proposta por um Senador. Por fim, se fosse aprovada nas duas Casas, seguiria para a sanção da Presidência da República.

Portanto, para o projeto fazer todo o percurso necessário para se tornar realidade, primeiramente, o movimento precisava contar com um "político aliado", com mandato, que apresentasse uma proposta de decreto legislativo, convocando a realização do plebiscito. Em seguida, precisaria contar com uma imensa articulação nos bastidores do Congresso Nacional, para negociar, convencer e tornar possível que o projeto fosse votado e aprovado, apesar dos desafios colocados à tramitação de propostas para criação de novos estados ${ }^{9}$.

Com esse quadro em mente, deixa de ser surpreendente o fato de que doze anos separaram o dia em que foi protocolado o projeto de decreto legislativo que, no final, provocou a consulta plebiscitária em 2011 e a data de sua aprovação no Congresso (Brasil 1999, 2011). Vemos também como os procedimentos necessários para o encaminhamento da luta determinavam desafios particulares à construção da mobilização, especialmente se levarmos em conta a heterogeneidade dos atores, que

9 Projetos de decretos legislativos para a convocação de plebiscitos para criação de novos estados possuem uma regulamentação específica. Conforme a lei 9.709/1998, propostas dessa natureza consistem em uma "questão de relevância nacional", por isso só podem ser encaminhadas se ratificadas por no mínimo um terço dos membros que compõem qualquer das Casas do Congresso Nacional (Brasil 1998). Se ratificada, em seguida, deveria ser encaminhada à Comissão de Constituição e Justiça, para ser avaliada por um relator. Somente após a aprovação na Comissão, o projeto tornar-se-ia apto a ser inserido na pauta para ser debatido pelos congressistas, entrando em uma fila de propostas, de onde só sairia com muita articulação e pressão política. No caso do estado do Tapajós, o trânsito completo do projeto entre a apresentação e a realização do plebiscito, em 2011, durou mais de dez anos. 
precisavam ser favoráveis para que o projeto seguisse caminhando e ganhando força, tanto entre o meio político-partidário quanto entre a população da região. A necessidade de construir um raio amplo de atuação e de produzir frentes diversificadas de convencimento me pareceu ser o terreno onde se desenrolavam os principais dilemas morais enfrentados pelos militantes dirigentes do movimento e onde residiam as principais contradições do discurso dirigido para dentro da região.

Nesse ponto, é interessante recuperar as principais motivações associadas à conquista dos votos necessários para a aprovação do plebiscito no Congresso Nacional, em 2011. Seguindo a retórica utilizada nos estudos de viabilidade econômica (Coimbra 1993, 1997; Pró-oeste \& Pró-Estado do Tapajós, 1996; Costa \& Pacheco 2011) e em relatórios técnicos que compunham o processo (Brasil 1990), e o perfil dos representantes políticos que militavam a favor da causa dentro do Congresso Nacional ${ }^{10}$, deparei-me com um desenho de estado do Tapajós perfeitamente alinhado aos interesses da bancada ruralista, que via no projeto uma oportunidade para fazer andar obras de infraestrutura que permitiriam consolidar um corredor de exportação de grãos bem mais lucrativo a partir dos portos de Santarém e Itaituba (Torres 2005; Alarcon et al. 2016). Essa linguagem, apesar de muito eficaz para mobilizar a força política necessária para "fazer o projeto andar" naquele espaço, parecia ser "incompatível" com as expectativas de grande parte dos militantes e apoiadores do projeto na região.

De modo geral, a base das "críticas" e "justificações" apresentadas tanto por militantes dirigentes do Instituto Cidadão Pró-Estado do Tapajós (ICPET) ${ }^{11}$ quanto por intelectuais e integrantes de movimentos sociais considerados de esquerda, em apoio ao projeto, passava pela rejeição à ideia de um "Estado" que se fazia “presente” apenas para "explorar” e por denúncias de uma lógica de gestão que determinava que "pouco retornasse para a região", alimentando continuamente sua condição de precariedade. No quadro dessas formulações, deparei-me com

10 Para maiores detalhes sobre as articulações realizadas nesse contexto, ver Bemerguy (2019).

11 Segundo me relataram meus interlocutores e conforme apresenta Dutra (1999), a primeira instituição fundada com o objetivo de lutar pela criação do estado do Tapajós foi criada informalmente em 1985 e passou a ter personalidade jurídica em 1991, nomeada de Comitê Pró-Criação do Estado do Tapajós. Desde então, o coletivo organizado para lutar pelo projeto teve inúmeros desdobramentos, fragmentando-se em mais de uma instituição (Frente Popular PróEmancipação do Estado do Tapajós; Fórum Permanente pela Criação do Estado do Tapajós), unindo-se novamente em 2004 (Movimento pelo Plebiscito e pela criação do Estado do Tapajós) para, por fim, ser renomeado como Instituto Cidadão Pró-Estado do Tapajós (ICPET), em 2011. Até a data de submissão desta publicação, a entidade, que possuía personalidade jurídica, estava sediada em sala cedida no prédio da Câmara dos Vereadores de Santarém, era a única a responder pelo movimento pela criação do estado do Tapajós e permanecia em atividade. 
posições estruturadas tanto por meio de denúncias sobre a "ausência do Estado" em serviços básicos, como educação, saúde e segurança, quanto por anseios em criar um "novo Estado de fato" na região, o que, em algumas situações, acabava por projetar no Tapajós uma possibilidade de mudar a lógica de gestão desenvolvimentista pensada para a Amazônia como um todo. Em um manifesto produzido através da articulação de diversos movimentos sociais no contexto da campanha para o plebiscito em Santarém, podemos observar as evidentes dissonâncias entre as posições apresentadas até aqui.

No dia 19 de setembro de 2011, a Articulação Popular Pró-Tapajós (APPT) divulgou um documento chamado "77 razões pelo Tapajós Sustentável”. Formada por diversas organizações e movimentos sociais da região oeste do Pará, como Sindicato dos Trabalhadores Rurais, Associações de Mulheres, Federação de Associações de Bairros, Comunidades Indígenas e Quilombolas e organizações não governamentais, a APPT se apresentou como uma "campanha paralela", como um contraponto crítico às "alianças suspeitas", feitas no bojo da campanha oficial, e, assim, justiçaram votar pelo SIM.

- Pela necessidade de colocar na ordem do dia o reconhecimento dos anseios dos povos indígenas, dos quilombolas, dos extrativistas, das mulheres, dos pescadores, dos assentados, dos agricultores familiares.

- Porque não queremos criar um estado a qualquer custo. Não queremos criar um Estado para os políticos corruptos. Queremos um Estado sem ficha, queremos um Estado decente para todos(as).

- Porque não queremos um Estado para as grandes empresas fazerem o que querem; queremos mudar a história da região, de celeiro de recursos que enriquece outras regiões e países para uma região que usa a sua riqueza para melhorar a vida do seu povo.

- Porque somos contra o modelo de desenvolvimento que gera miséria e transfere nossas riquezas para outras regiões em detrimento da melhoria da qualidade de vida da população.

- Porque o que nos move não é a defesa do capital, mas a nossa consciência de que queremos traçar o nosso futuro e o nosso destino.

- Porque precisamos valorizar o produtor rural e a produção familiar, que tem ficado marginalizada pela valorização do agronegócio (pecuária, soja, madeira etc).

- Queremos nos livrar da oligarquia corrupta que domina historicamente o Estado do Pará que quer que as pessoas da região permaneçam miseráveis e aos seus serviços.

- Porque o novo Estado permitirá a valorização das comunidades tradicionais e ribeirinhas da região.

- Porque o novo Estado permitirá pensar em projetos de sustentabilidade que levem em consideração as especificidades locais historicamente não reconhecidas.

- Pela necessidade da regularização fundiária e da presença do Estado e dos seus órgãos para garantir a terra a quem precisa e direitos sociais e culturais do povo.

- Por uma infraestrutura de energia, rodovias e estradas que quebre o isolamento e garanta o desenvolvimento sustentável da região. - Para sermos referência de preservação e conservação dos recursos naturais ao contrário do que é hoje o Estado do Pará, que é referência em violência no campo, desmatamento, trabalho escravo.

- Porque a região oeste é a última 
fronteira verde que forma o atual Estado do Pará, e o Estado do tapajós é a oportunidade que temos para preservá-la (Pró-Tapajós 2011).

Desde esse recorte do debate público, acredito que se possa dimensionar o tamanho das incompatibilidades e da força alcançada pelo projeto, apesar dos antagonismos entre as posições.

Nesse caso, uma boa maneira de visualizar o tamanho dessa força seria imaginar o retrato de um palanque onde estivessem, lado a lado, figuras importantes envolvidas em diferentes níveis de articulação do projeto e expoentes de cada um dos grupos com alguma expressão no debate público que tomou conta da cidade de Santarém durante a campanha para o plebiscito. Nesse quadro, teríamos Mozarildo Cavalcante ${ }^{12}$ e Lira Maia ${ }^{13}$, dois políticos conhecidos pela atuação em favor do agronegócio nacional e articuladores centrais do projeto de decreto que levou à realização do plebiscito em 2011; integrantes de movimentos sociais e de organizações não governamentais ligados à luta pela terra e pela preservação ambiental; integrantes de setores combativos do movimento estudantil local; lideranças indígenas; representantes da elite empresarial e comercial da cidade; prefeitos e ex-prefeitos de Santarém de partidos conhecidos por disputarem entre si; artistas e historiadores locais reconhecidos; o bispo da diocese de Santarém à época; e integrantes de setores progressistas da Igreja Católica na cidade. Por fim, foram $98,63 \%$ de votos SIM.

Em Santarém, no "tempo do plebiscito" ${ }^{14}$, as “alianças suspeitas" feitas em nome da causa e a clara sobreposição entre a luta pela criação do novo estado e os interesses de setores da bancada ruralista no Congresso Nacional (Dutra 1999;

12 Ex-senador, eleito pelo estado de Roraima, por onde exerceu quatro mandatos, dois como deputado federal (19831987/Partido Democrático Social; 1987-1991/Partido da Frente Liberal) e dois como senador (1999-2007/Partido da Frente Liberal; 2007-2015/Partido Trabalhista Brasileiro), todos eles como representante do estado de Roraima. Foi o autor do projeto de decreto legislativo que provocou a realização do plebiscito em 2011 (Brasil 1999, 2011). Considerado parte da bancada ruralista (Costa 2012b), ferrenho opositor no Senado aos processos de demarcação de terras indígenas em Roraima e nome conhecido no debate sobre os direitos indígenas, por ser de sua autoria uma das propostas de emenda constitucional (PEC 038/1999) que tem como objetivo transferir ao Senado Federal a competência de aprovar o processo de demarcação de terras indígenas.

13 Considerado membro da bancada ruralista, ao longo de sua vida pública, Maia exerceu cinco mandatos, todos no estado do Pará: um como deputado estadual (1995-1996/Partido da Frente Liberal), dois para atuar como prefeito da cidade de Santarém (1997-2000; 2001-2004/Partido da Frente Liberal) e dois como deputado federal (2007-2011/Partido da Frente Liberal; 2011-2015/Democratas). Foi inúmeras vezes acusado e investigado por suspeita de corrupção e, no período de realização do plebiscito, estava conhecido pelo número recorde de processos que corriam contra ele no Supremo Tribunal Federal, quatorze - quatro deles eram ações penais. Durante a campanha, ainda como deputado, Maia foi o presidente da Frente Parlamentar em Defesa da Criação do Estado do Tapajós. O deputado era conhecido como "representante" da luta e indicado ao longo das entrevistas como "o" político que eu deveria procurar para falar sobre a questão.

14 Inspirada pelas reflexões de Palmeira \& Herédia (1995), a referência ao “tempo do plebiscito" nesse ponto serve para destacar um tempo em que a política foi experienciada de forma particular por diversos atores na cidade. 
Bemerguy 2019) ${ }^{15}$ foram utilizadas para justificar acusações de que o movimento pela criação do estado do Tapajós seria, de fato, um "movimento separatista de políticos oportunistas", que somente havia conquistado tanto apoio na região porque o povo havia sido manipulado a acreditar em um projeto que jamais seria como esperavam. Assim, diante da necessidade de responder a essas acusações, os militantes dirigentes, responsáveis pela articulação do projeto "para cima”, retomavam o quadro das burocracias determinadas para a criação do novo estado, a fim de produzir a "política” como um incontornável, como um espaço por onde precisavam transitar para "fazer acontecer" o "sonho" de criar o estado do Tapajós. Desse modo, apresentavam-se críticos ao conjunto de "interesses mais amplos" que atravessavam o trâmite do projeto nos espaços institucionais da "política" e afirmavam-se como personagens diferentes dos "políticos": eram apenas "militantes" que faziam um "trabalho voluntário" em nome de sua "consciência enquanto cidadãos" e, sobretudo, pelo “amor à região".

Nesse sentido, a própria noção de militância era construída a partir de um investimento continuado em produzir uma fronteira entre o que era o movimento social e o que era a "política", ainda que, na prática, essa separação não fosse possível. Para além do fato de as particularidades da tramitação estabelecerem um entrelaçamento incontornável entre o projeto e o meio político-partidário, desde seu início, a mobilização contou com o apoio e com a participação direta de políticos profissionais e, em vários momentos de sua história, se pode observar a produção de um investimento continuado em institucionalizar a luta. Esse imbricamento teve efeitos concretos no cotidiano da construção da mobilização. Assim, por exemplo, desde meados de 2005, o movimento passou a contar com uma sala no prédio da Câmara Municipal de Santarém para desenvolver suas atividades. No mesmo período, alguns de seus integrantes conseguiram articular a inserção de um artigo na lei orgânica municipal, onde estão destacados os esforços que deveriam ser despendidos pelo município para viabilizar a criação do novo estado e, anos depois, sempre percorrendo as negociações da "política", conseguiram que a pauta ganhasse ainda mais espaço dentro do Legislativo, quando, em 2012, como uma resposta ao resultado do plebiscito, foi

15 O destaque ao grande interesse de setores do agronegócio no projeto de asfaltamento da rodovia é fundamental para entender o quadro da controvérsia que se desenha em torno da disputa pela criação dos novos estados no Pará, contudo, nos limites deste trabalho, não será desenvolvida uma análise mais aprofundada acerca do lugar estratégico ocupado pela rodovia BR-163 na ampliação e consolidação da frente de expansão agrícola na região. Para este debate, ver Torres (2005), Castro (2008a), Castro (2008b), Bernardes \& Filho (2010), Costa (2012a) e Almeida (2013), Alarcon et al. (2016). 
criada a Coordenadoria de Integração Regional e de Apoio à Criação do Estado do Tapajós. Durante alguns anos, a Coordenadoria e a direção formal do movimento foram exercidas pela mesma pessoa.

A fronteira, portanto, dizia muito mais sobre uma manutenção e reafirmação dos valores que deveriam orientar a luta do que sobre a prática concreta da militância. Desse modo - especialmente para aqueles com trajetórias que, por razões diversas, passavam pela atuação profissional em espaços profissionais da política, como a prefeitura municipal ou setores locais de partidos nacionais -, a manutenção desses limites passava pelo êxito em convencer que não era a "política" que motivava a luta. Desse modo, na medida em que os procedimentos burocráticos para "fazer o projeto andar" tornavam "necessário" que os militantes dirigentes atravessassem constantemente a fronteira que produziam entre os espaços do movimento social e os espaços da "política", estes eram pressionados a administrar cuidadosamente sua atuação, para não dar espaço para afirmação de que a causa teria sido "contaminada" pelos "interesses escusos", correntemente associados ao meio político-partidário. Nesse contexto, tornava-se fundamental mobilizar argumentos que "provassem" o caráter "desinteressado" de sua luta. Nesse quadro, o destaque aos afetos tornavase central.
O discurso em resposta às acusações de “oportunismo político” aparecia em falas "emocionadas" sobre uma militância em nome de um movimento social popular, de raízes históricas profundas, que tinha como objetivo lutar pelo projeto de Estado que acreditavam e pela sua emancipação e reconhecimento enquanto um povo que lutava em nome do sentimento de pertencer a uma região com características físicas, históricas e culturais distintas, que era roubada constantemente pelas políticas colonialistas as quais subalternizavam a Amazônia. No quadro dessas "justificações", observei, portanto, como a dimensão do sentimento e do reconhecimento afetivo, fundamentado na História, era entendida como um contraponto eficaz ao "interesse" e que, em alguns casos, poderia ser mobilizada ativamente como uma estratégia na construção da mobilização. Penso, no entanto, que o lugar dos afetos na luta ultrapassa o acionamento ativo e que uma maior compreensão da amplitude dos efeitos produzidos poderá ser possibilitada por uma leitura interessada da forma como dados históricos eram recuperados para afirmar a perenidade da causa.

Reconstruído historicamente a partir de um exercício de apropriação interessada do passado (Hobsbawm \& Ranger 2002) e de uma leitura particular da história de ocupação e colonização da Amazônia, nesse ponto o projeto do estado do 
Tapajós é caracterizado pelos militantes como um "sonho abortado" de um povo que há quase dois séculos de luta pela autonomia de "construir seus próprios destinos". Nesse sentido, grande parte das histórias que pude ouvir passava por uma linha narrativa de produção sobre si e sobre a luta em que reivindicavam laços de pertencimento, acionando um longo histórico de revoltas que marcava a trajetória do "povo da região": como "colonos da Coroa Portuguesa", como "cabanos", “amazônidas", "nortistas”, "militantes do Tapajós". Nesse contexto em particular, apresentaram-me elaborações sobre a luta desenhando e mobilizando distintos processos de reconhecimento afetivo com o lugar, com a cidade e com a região. Argumento que essas "invenções" sobrepostas passaram a se coproduzir explorando a polissemia do termo “Tapajós”. Assim, a atenção aos múltiplos sentidos que atravessam esse referente tornou-se um exercício fundamental para dimensionar de que maneira a linguagem dos afetos compunha as justificações que permitiram "fazer crescer" a crença na legitimidade do projeto pela criação do estado do Tapajós e garantir uma profunda adesão ao projeto em Santarém, cidade pensada para ser sua futura capital.
Nesse ponto especificamente, penso que se esgota a rentabilidade de uma análise centrada na pragmática, na medida em que acredito que a dimensão afetiva não poderá ser analisada em toda sua complexidade se partirmos de um entendimento de que toda manifestação de sentimento será uma resposta racional ou uma estratégia de mobilização. Não desejo promover um julgamento sobre a franqueza do reconhecimento afetivo reivindicado como motivação para a luta, mas de refletir de maneira ampla sobre como essa dimensão compõe o processo de feitura do estado do Tapajós e sobre como produziu efeitos para além do plano argumentativo e performático do convencimento.

\section{TAPAJÓS: DOS AFETOS PRODUZIDOS POR ENQUADRAMENTOS DE UMA PALAVRA-ATO ${ }^{16}$}

No contexto da presente proposta para se refletir sobre os múltiplos sentidos relacionados ao termo Tapajós, é importante destacar que as palavras e a fala possuem um lugar particular na produção de minha análise. Inspirada pelo que propõem Austin (1975) e Foucault (2010), penso que a fala é ação em si mesma, e que os discursos são práticas que sistematicamente

16 Expressão inspirada em Austin (1975), utilizada por Vianna (2014), para refletir sobre as zonas semânticas e de significação produzidas por certas palavras-ato na "luta por justiça" de mães de jovens assassinados pela polícia na cidade do Rio de Janeiro. Minha reflexão sobre a força particular de certas "palavras" no processo de construção de uma "causa" foi inspirada pelo trabalho da autora. 
conformam e são conformados por relações de poder. Nos termos de uma abordagem pragmática, analiticamente, busquei manter sempre em mente o poder particular das palavras em fazer e desfazer realidades. A atenção aos usos de certos termos e a centralidade que esses referentes ganharam ao longo do trabalho foram produzidas a partir do diálogo com esse debate.

Além disso, acredito que o efeito produzido por certas "palavras-ato", na situação de disputa que descrevo, deve ser dimensionado à luz do que destaca Bourdieu (1989) sobre as enunciações em torno de um anseio regionalista, especialmente quando o autor destaca que, no contexto da luta pelo reconhecimento da região, qualquer enunciado sobre ela pode contribuir para o reconhecimento ou não da sua existência. No "regionalismo", portanto, enquanto um caso particular de disputa pelo simbólico, em que os atores envolvidos lutam para tornar hegemônica uma representação particular sobre uma "região", certas palavras e discursos podem ser capturados para produzir um efeito de "discurso de consagração" (Bourdieu 1989:118-120).

Por fim, a centralidade das palavras-ato se colocou pelo fato de que, ao longo da pesquisa, observei que diversas referências ao termo "Tapajós” eram valoradas por meus interlocutores como "provas" de que o estado era um "fato consumado" e de que o "Pará já estava dividido".

Nessas elaborações, os afetos inscritos por/ com o termo me pareceram fundamentais. No horizonte dessas discussões, esclareço que minha escolha em tratar as emoções e os sentimentos envolvidos no contexto da mobilização pela criação do estado do Tapajós como a linguagem dos afetos que compõe a luta se inspira em uma leitura interessada das reflexões de Butler (2015), sobre os "enquadramentos" voltados à mediação e ao controle de reações afetivas frente a situações de violência.

Ao destacar como os registros da guerra estão a serviço da produção de uma afetação regulada que visa definir quais vidas perdidas provocam nosso luto e quais não, a autora nos convida a refletir sobre as relações de poder e disputa que mediam nossas respostas afetivas às mortes provocadas em contextos de guerra. Assim, indicando como a opinião pública possui um papel importante na manutenção da crença da legitimidade de uma guerra, Butler (2015) argumenta que esse esforço de regulação da comoção precisa ser contínuo e que se dirige, sobretudo, ao domínio das reações afetivas primárias, ou seja, ao domínio das primeiras emoções que nos tomam ao nos depararmos com uma notícia de um bombardeio, com imagens de práticas de tortura, com o número de mortos produzidos por uma guerra. 
Inspirada em Butler (2015), nessa sessão, buscarei, então, "enquadrar os enquadramentos" produzidos ativamente por meus interlocutores ao visarem mediar as conclusões interpretativas e as reações afetivas dos moradores da região oeste do Pará ao projeto de criação do novo estado. Tratarei, portanto, de explorar uma perspectiva interessada em refletir como a expressão de uma emoção é mediada por projetos e relações de poder. Penso também que a escolha se justifique na medida em que me interessa explorar não só o horizonte de sentimentos sedimentados que meus interlocutores afirmavam motivar a luta e sua dedicação à militância, buscando diferenciar-se dos "políticos", mas também o modo como ativamente buscavam produzir afetos, em vias de garantir apoio ao projeto entre os "filhos da região", ou seja, como as reações afetivas se tornavam objeto e objetivo da mobilização social.

Nesse quadro, ainda em diálogo com Butler (2015), me interessa explorar também a dimensão primária de afetação produzida pela invocação da palavra-ato Tapajós - o universo das primeiras reações afetivas que o termo pode despertar e o modo como essas reações podem ser determinantes para o curso de um projeto político. Nesse sentido, pretendo demonstrar como determinados enquadramentos da polissemia do termo Tapajós foram fundamentais para capturar uma série de afetos difusos produzidos pela palavra-ato, e como a mobilização social regionalista cresceu explorando os efeitos dessa afetação. Com essas questões em mente, irei apresentar de que maneira a afirmação de que a luta pela criação do novo estado era fruto de um sentimento de pertencimento a uma região distinta e explorava efeitos de uma capilaridade produzida pela construção de linhas de sobreposição entre distintas "realidades feitas" pela polissemia da palavra-ato "Tapajós". Passo, agora, para a descrição de cenas que me permitirão apresentar alguns dos muitos sentidos associados ao termo.

\section{1. "SANTARÉM DO TAPAJÓS"}

Três de março de 2016. Nesse sábado de manhã, saí cedo de casa para encontrar com Ednaldo Rodrigues. Era a última entrevista que realizaria antes de retornar para o Rio de Janeiro. Jornalista de formação, professor universitário, naquele momento, ele estava trabalhando como coordenador de comunicação da Câmara de Vereadores de Santarém. Ouvi-lo era fundamental. Por mais de dez anos, Ednaldo atuara como secretário-geral do movimento, trabalhando voluntariamente, como faria questão de destacar em vários momentos de seu relato, de quase três horas, sobre a luta e sobre seu envolvimento com a militância. Ele era bom para "perceber as coisas" - 
me disse -, por isso muito de sua atuação passava pela elaboração de "estratégias de valorização". Uma delas ocorreu justamente em função do nome dado ao estado: Tapajós. "Em um determinado momento, lideranças de alguns municípios nos questionaram sobre isso" - destacou - "Por que o nome do estado deveria ser Tapajós se o rio Tapajós não banhava grande parte dos municípios que fariam parte do novo estado?"17 (Ednaldo Rodrigues, entrevista, Santarém, 3 mar. 2016).

Ao longo da conversa, ficaria claro que a tensão, na verdade, residia em um incômodo com o fato de os santarenos "tomarem como certo o fato de que seriam capital”. Como o Tapajós (rio) banha Santarém, a escolha desse nome, que teria sido feita à revelia de municípios que não se estruturam no eixo fluvial, era entendida como uma espécie de reforço à certeza dos santarenos de que a posição de capital não estava em disputa. "Nos acusaram de querer criar o estado de Santarém! Aí o movimento precisou redirecionar". As lideranças queriam garantir a possibilidade de sua cidade pleitear a posição de capital e, por isso, precisou haver todo um trabalho para que esse conflito em torno do nome não prejudicasse a possibilidade de os municípios se unirem em torno do projeto. "Aí nessa questão a gente tinha uma situação que deixava essas lideranças dos outros municípios muito incomodadas". Ele contou, então, que durante muito tempo os radialistas santarenos referiamse ao lugar durante suas programações falando: “Santarém, a futura capital do estado do Tapajós!".

Então, como eu sou da área da imprensa
e nessa época eu também era do
sindicato dos radialistas, fizemos uma
reunião e colocamos pra eles: vocês
nos ajudam muito, mas nos ajudariam
muito mais se tirassem "a capital do
estado do Tapajós”, vocês só precisam
dizer 'Santarém do Tapajós". E se você
ouvir rádio hoje, ainda tem muitos
amigos da imprensa que falam dessa
forma: Santarém do Tapajós, em vez
de Santarém do Pará. Por que é uma
questão cultural, mas você tem que ir
ao longo do tempo solidificando isso,
né? É um processo (Ednaldo Rodrigues,
entrevista, Santarém, 3 mar. 2016).

\subsection{INSCRIÇÕES DILUÍDAS EM UMA}

\section{PAISAGEM "FAMILIAR"}

“Telma, hoje você anda na região oeste do Pará, a começar por Santarém, e você tem tudo: Shopping Tapajós, Bateria Tapajós, não sei o que Tapajós, tem tudo!" - destacou Ednaldo, sorrindo consigo mesmo antes de continuar, me contando orgulhosamente como havia contribuído para produzir aquelas inscrições. Eu estava muito curiosa em saber mais sobre aquelas nomeações. Em 23 anos vivendo em Santarém, somente algumas semanas antes, quando retornei para iniciar o trabalho de campo para a pesquisa da

17 Dos 27 municípios que estavam incluídos no projeto do plebiscito, nove eram banhados pelo rio: Santarém, Itaituba, Belterra, Aveiro, Novo Progresso, Juruti, Jacareacanga, Rurópolis e Trairão. 
dissertação, havia notado esse número considerável de estabelecimentos comerciais e prédios públicos identificados com o nome Tapajós. Enquanto Ednaldo falava, eu relembrava minha sensação de surpresa, ao passar a ver Tapajós por todos os lados naquela paisagem familiar:

\begin{abstract}
Isso aconteceu porque as pessoas têm esperança que o estado seja criado, porque eles precisam ter, eles sentem a necessidade de apoiar e como que eles apoiam? Colocando no nome do seu empreendimento o nome do estado! Mas isso foi construído, isso aí não foi gratuito, isso aí não surgiu do nada (Ednaldo Rodrigues, entrevista, Santarém, 3 mar. 2016).
\end{abstract}

Destacou Ednaldo, em um tom que deixava claro o valor que atribuía ao "privilégio de ter feito parte de um grupo de pessoas que trabalhou estrategicamente isso".

\begin{abstract}
Quantas e quantas vezes fomos a reuniões na Associação Empresarial e eles diziam assim: "Olha, as pessoas têm a ilusão de que essa Associação empresarial tem dinheiro, mas nós só somos uma entidade, assim como é o instituto [ICPET]. Bom, essa fala já era pro movimento não pedir nada, né? (Ednaldo Rodrigues, entrevista, Santarém, 3 mar. 2016).
\end{abstract}

"A ideia era pedir apoio sim, financeiro e tudo", mas, segundo Ednaldo, ele conseguiu "redirecionar a conversa”. E seguiu compartilhando o orgulho de, naquele dia, ter conseguido conquistar mais um apoio fundamental para a causa:

Eu disse: "Olha, minha gente, mas vocês não têm só isso pra nos doar. Se vocês reunirem com seus associados e pedirem pra eles nominarem os seus empreendimentos com o nome Tapajós, isso aí é um outdoor que vai ficar para sempre, até eles passarem pra filhos e netos, então é uma grande ajuda" (Ednaldo Rodrigues, entrevista, Santarém, 3 mar. 2016).

E encerrou sua história com um ar de vitória, dizendo: “Então isso foi construído, né?". E assim, produzindo inscrições no espaço da cidade, o movimento "inventou" o cenário de uma luta histórica, passada de geração em geração.

Então nós temos hoje vários outdoors aí pela rua, que é o nome dos empreendimentos, gratuitamente, e que todas as pessoas quando falam “olha, é lá na bateria Tapajós”, "é lá no supermercado Tapajós”, sabe? Então, quer dizer, a construção de um estado não se dá apenas por um recorte geográfico, mas é um conjunto muito grande de coisas (Ednaldo Rodrigues, entrevista, Santarém, 3 mar. 2016).

\subsection{A LUTA DOS ANTEPASSADOS E A CAMINHADA PELA HISTÓRIA}

21 de fevereiro de 2016. Sigo para a vila de Alter do Chão para entrevistar Jackson Matos, engenheiro florestal de formação, natural de Santarém, doutor em desenvolvimento sustentável pela Universidade de Brasília e professor do Instituto de Biodiversidade e Florestas da Universidade Federal do Oeste do Pará. Somente nesse dia soube que durante a campanha para o plebiscito ele, que "nunca havia participado ativamente do movimento, mas que sempre foi um defensor da causa do Tapajós", aceitou o desafio 
de ser o porta-voz do SIM para responder aos questionamentos da população e da imprensa sobre a questão ambiental. A paixão com que Jackson falava sobre a causa logo chamou a minha atenção. Como especialista que era, falou-me com muita propriedade sobre o projeto de estado que defendia e sobre sua crença na possibilidade de se realizar um projeto de desenvolvimento sustentável para a Amazônia, respeitando a natureza e as populações tradicionais da região. A conversa foi extensa! Assim, ao longo da tarde, pude acompanhar Jackson passar de análises técnicas serenas em tom professoral e didático a sobressaltos na voz e batidas na mesa ao relatar, enraivecido, as traições sofridas pelo movimento ao longo da história. Por um lado, buscou ser crítico e realista sobre as limitações impostas pela política e pela "briga insana entre os partidos pelo poder”, por outro, não conteve a emoção ao falar sobre como esse "sonho" lhe foi transmitido de berço e sobre como seu avô teve a tristeza de morrer sem ver concretizado aquele desejo.

Só pra te mostrar um pouco desse sentimento. $\mathrm{O}$ meu avô morreu com 94 anos, ele ia fazer cem anos esse ano, se tivesse vivo. Aí, uma vez, eu conversando com ele, já tava bem baqueado, sofrendo de Mal de Parkinson, Alzheimer, essas coisas. Mas ele tinha momentos de lucidez muito grandes. Aí, um dia eu perguntei: "Vô, o senhor ainda quer chegar aos cem anos?". Aí, ele falou bem assim: "Se for pra ver o estado do Tapajós, eu quero!". Veja só, ele não teria condições nenhuma mais de tá vivo com cem anos, estaria se arrastando, mas se fosse pra ver ele queria. Então, esse é o sentimento dos nossos antepassados (Jackson Matos, entrevista, Santarém, 21 fev. 2016).

"Eu nasci e cresci numa casa com aquela senhora ali" - destacou Jackson, indicando a foto, pendurada na parede, onde se via uma senhora de aparência humilde. "Ana Tapajós era o nome dela, minha bisavó. Então é isso, esse nome, Tapajós, sempre foi algo que norteava nossa vida: avenida Tapajós, o rio Tapajós... Eu vejo isso, eu ando por Santarém e eu sinto que eu estou caminhando pela nossa história” (Jackson Matos, entrevista, Santarém, 21 fev. 2016).

\subsection{MÚLTIPLAS FORMAS DE PERTENCER}

Sete de setembro de 2011. Dia de encerramento das atividades da semana da pátria em Santarém. Na cidade, o apreço pelas fanfarras, a força dos pertencimentos de bairro e a rivalidade entre certas escolas, que se orgulham da tradição de oferecer uma excelente formação musical, transformam os desfiles de celebração à Independência em um evento muito apreciado. O cenário reservado aos espetáculos é a "frente da cidade”. Ali, na primeira rua que se vê ao se chegar ao lugar pelas águas, passam as bandas marciais, enquanto os alunos de cada escola marcham ao som de versões adaptadas de hits do momento ou clássicos da 
música brasileira ou internacional. O clima é de competição e tudo isso se desenrola sob os olhos de uma "orla" lotada, como só se vê em dias de festa.

Fazia não mais do que três meses que chegara à cidade a notícia de que naquele ano "finalmente seria realizado o plebiscito para criar o estado do Tapajós". O clima de euforia em torno da aprovação da consulta logo gerou diversas iniciativas de eventos para celebrar o SIM. Nesse contexto, a Academia de Letras e Artes de Santarém anunciou que a semana da pátria seria encerrada por um espetáculo conectado ao "momento social e político vivido aquele ano”. "Canta Tapajós, Independência!” - esse foi o nome dado ao evento onde se apresentaram diversos cantores e poetas locais. Cristina Caetano foi uma delas. Ela era uma jovem cantora muito conhecida na cidade, especialmente por sua composição de um carimbó em que celebrava "ser da região". Nesse dia, em um palco em frente ao rio Tapajós, ornamentado com uma enorme faixa em que se podia ler à distância os dizeres "SIM! INDEPENDÊNCIA JÁ!", ela cantou:

\author{
Sou cabocla, isso eu não nego a \\ ninguém \\ Meu traço forte vem do Norte, eu sou \\ de Santarém! \\ Sou cabocla parida no Tapajós \\ Danço Lundú, o Siriá, mas o meu \\ carimbó ${ }^{18} \ldots$ isso é pai d'égua, \\ maninha ${ }^{19}$ ! \\ Quem pode ter culpa de nascer tão \\ bem? \\ Vou do acari ${ }^{20}$ ao piracuíi ${ }^{21}$, vou de \\ Santarém! \\ Quem pode ter culpa, se o Tapajós \\ pode ser um rio caudaloso ou Sebastião \\ virtuoso? \\ (Música: "Sou Cabocla"/Cristina \\ Caetano)
}

Fazendo reverências ao rio à sua frente e dançando pelo palco, ela encerra sua apresentação, dizendo: "Esse é o carimbó do Tapajós!".

\section{REALIDADES E AFETOS SOBREPOSTOS: O TAPAJÓS É UM "FATO CONSUMADO"}

Inspirada nas reflexões de Weber (1999) sobre os processos de elaboração de uma comunidade étnica e de uma comunidade nacional, peço que as situações descritas ao longo do texto não sejam interpretadas como uma imagem estática de uma "comunidade" em um determinado momento do tempo, mas sim como registros de momentos do

18 Lundu, siriá e carimbó são ritmos e danças locais típicas.

19 "Pai d'égua" é uma expressão corriqueira no Pará para se referir de maneira bastante positiva a situações, relações e objetos.

20 Peixe de água doce de tipo cascudo bastante presente no rio Amazonas e em seus afluentes. Pelo sabor marcante e pela dificuldade de ser encontrado fora da Amazônia, é considerado uma comida regional.

21 O piracuí é uma farinha de peixe usualmente produzida com a carne do acari, em um processo de cozimento, secagem e moagem que garante sua conservação. Apesar de também ser produzido em alguns outros pontos da bacia amazônica, em Santarém é apropriado como uma iguaria típica da cidade. É utilizado no preparo de diversas receitas, as mais difundidas são os bolinhos (como o de bacalhau) e a farofa (piracuí, farinha de mandioca e banana). 
processo de "comunização", ou seja, como descrições sobre os meios concretos por onde têm se elaborado a crença e o argumento de que na região oeste do Pará existe um passado, uma identidade comum e um "sentimento coletivo" que alimenta o desejo pela emancipação. Nesse sentido, para começar a seguir as linhas de afeto que atravessam ou são mobilizadas em torno da palavra-ato "Tapajós”, é interessante olhar com mais atenção para essa última cena descrita. Para tanto, é importante destacar que a música escolhida por Cristina Caetano para compor aquele evento em nome da "independência da região" não foi composta para aquele contexto. Não era, portanto, uma música de campanha e esse ponto é fundamental para compreender de que modo o "Tapajós", referenciado por Cristina em sua música, se torna uma metáfora de toda a força da "comunização" (Weber 1999) possibilitada pela polissemia.

Nesse ponto, é importante destacar brevemente que uma particularidade importante de se manter em mente ao se fazer uma reflexão sobre elementos que atravessam o pertencimento às cidades da Amazônia é o fato de que, em determinado período da história de ocupação da região, o controle de certos pontos estratégicos para a circulação pelos rios foi um eixo que estruturou a colonização, produzindo fixações em seu entorno que, em alguns casos, após diversos processos, levaram à formação de vilas, comarcas, cidades (Castro 2009). Nesse sentido, ao se referirem à Santarém, meus interlocutores, por exemplo, retomavam a história do município (Reis 1979; Fonseca 1990) para estabelecer que a origem da cidade datava de ações de colonização portuguesa ainda no século XVI. Assim, sedimentavam o caminho para a caracterizarem como uma "cidade histórica", reivindicando uma distinção entre a cidade e o que chamavam de municípios de "colonização recente", principalmente aqueles que teriam sido criados como resultado/efeito das ações de intervenção promovidas pelos governos da Ditadura Civil Militar, com os projetos de colonização dirigidos em torno da abertura das rodovias.

Santarém, enquanto uma "cidade histórica", portanto, era produzida como uma cidade originada por ações de colonização estruturadas em torno de dois rios: o Tapajós (águas azuis) e o Amazonas (águas amarelas), que se encontram, sem se misturar, na "frente da cidade". O lugar desse passado e os efeitos desse orgulho da beleza do "encontro das águas", especialmente do azul das águas das praias do rio Tapajós, que são "boas para mergulhar" e "ficar de bubuia ${ }^{22 "}$ - como dizem os

22 "Ficar de bubuia" é uma expressão corrente, utilizada para descrever afetivamente o ficar imerso nas águas por longo tempo, aproveitando o banho no rio Tapajós. A expressão faz referência a uma conhecida poesia musicada na cidade de Santarém: "Peixada na praia", de autoria de Emir Bemerguy e Wilson Fonseca. 
poetas locais -, ficam mais claros se observarmos que uma forma corrente de se referir ao lugar - o que inclui desde projetos de incentivo ao turismo a conversas de bar na beira do rio - é "Santarém, pérola do Tapajós". Talvez aqui ganhe mais sentido os termos da tensão relatada por Ednaldo entre os municípios que comporiam o novo estado, em função da escolha do nome “Tapajós” para nomeálo. Essa outra cena me permite destacar desde outro lugar o quanto elaborações sobre o ser santareno passavam pela mobilização da relação do lugar com o rio Tapajós.

A partir desse pano de fundo, podemos voltar à performance de Cristina Caetano para afirmar que em uma camada da cena temos apenas uma artista local apresentando uma cantiga em homenagem à sua cidade, colocando em destaque a centralidade dos afetos que os santarenos mobilizam em torno do rio. Em ritmo de carimbó, a artista manifesta seu orgulho em ser uma "filha da terra", entrelaçando ser santareno, ser do Norte e ser "parida no Tapajós”. Nessa primeira camada, esse Tapajós seria o rio. Mas uma segunda camada se coloca, se lermos a cena à luz do fato de que aquela cantiga estava sendo cantada em um palco produzido esteticamente para receber uma apresentação de celebração da "independência que a criação do estado do Tapajós proporcionaria para a região", um evento de campanha para o voto SIM no plebiscito. Nesse contexto, cantando pelo SIM ao estado do Tapajós, dançando, fazendo referências ao rio Tapajós, celebrando ser santareno, ser do Norte, Cristina Caetano nos permite observar como as realidades e os afetos produzidos por essa palavra-ato de múltiplos sentidos poderiam ser agenciados para fazer crescer a mobilização pela criação do novo estado.

Vemos, por fim, como, em função das sobreposições, a polissemia do termo é capturada para argumentar, por exemplo, que as materialidades e inscrições naquela paisagem que ambiguamente o movimento também reivindicava ter inventado eram manifestações espontâneas de um sentimento de pertencimento ao Tapajós (estado). O “Tapajós” na paisagem e o Tapajós na fala eram, assim, significados como "provas" de que o "estado já estava dividido" e as inúmeras linhas de afeto produzidas pela palavra-ato eram apagadas, permitindo, desse modo, que todas aquelas referências se transformassem em "provas" de um sentimento que vinha dos antepassados, legitimando a dimensão afetiva acionada para argumentar que a criação do novo estado seria apenas reconhecer formalmente o que já era um "fato consumado": aquela região não se reconhecia como parte do estado do Pará.

\section{CONSIDERAÇÕES FINAIS}

Interessada em compreender como o projeto 
de criação do estado do Tapajós alcançou uma enorme adesão na região oeste do Pará e uma "quase unanimidade" no município de Santarém, neste artigo, busquei destacar como análises sobre a adesão a projetos controversos podem ser adensadas pela atenção aos afetos e afetações capturados/agenciados/produzidos no curso de mobilizações sociais. Ao destacar como o plebiscito se tornou realidade a partir de um combinado de linguagens e argumentos-força que revelavam expectativas mutuamente incompatíveis acerca do que o projeto representaria para a região, tinha como objetivo demonstrar desde as nuances de uma situação empírica controversa às limitações de um quadro analítico centrado apenas na pragmática do "como fazer" das mobilizações ou em explicações "racionalistas" interessadas em "revelar" as razões que motivam os sujeitos com quem interagimos a apoiarem ou a resistirem a determinados projetos políticos (Goodwin et al. 2001). Em minha pesquisa, busquei compreender como foi possível produzir um "acordo" em meio às profundas dissonâncias existentes entre os muitos grupos, coletivos e indivíduos, que manifestaram apoio à criação do estado do Tapajós, em Santarém, no "tempo do plebiscito", e como, no final das contas, o projeto de criação de um novo estado foi produzido enquanto uma "causa" de toda uma região. Concluí que os afetos consistiam em uma dimensão fundamental a se considerar para apresentar uma resposta a essa questão, que, se não incorporada na análise, teria limitado minha compreensão sobre como as contradições observadas no plano das justificações centradas em dados duros a respeito dos índices de qualidade de vida na região ou na crença em diferentes projetos de desenvolvimento não anularam a possibilidade de sujeitos com expectativas díspares se posicionarem juntos, empunhando a mesma "bandeira". É importante destacar, contudo, que não a considero como "a" explicação para o processo de produção de adesão, mas como uma camada densa, e certamente produtiva, que, no caso analisado, pode ser lida como uma das linguagens a tornar possível o "acordo" entre os diferentes sins ao estado do Tapajós.

O "comportamento emocionado" possui um lugar importante em qualquer interação. Dependendo do contexto, certas demonstrações de emoção podem cumprir a função de enviar uma mensagem de sinceridade e convicção bastante poderosa em situações em que se busca persuadir outros atores sobre uma questão (Bailey 1993). Em alguma medida, concordo que certos enquadramentos pragmáticos de um "comportamento emocionado" podem ser eficazes para refletir sobre as performances corporais mobilizadas em interações motivadas pela disputa em torno de uma posição frente a um debate ou a 
uma situação específica. Entretanto, penso que, se permanecermos lendo a emoção e o sentimento somente na chave da estratégia, poderemos acabar sugerindo falsamente que os sujeitos com quem interagimos a todo tempo e de maneira consciente estipulam objetivos para cada uma de suas ações e que agem sempre "para obter o máximo de eficácia com o menor custo" (Bourdieu 1996:142). Essa leitura reduz a "carnatura" das relações sociais e limita incorporar seriamente em nossas análises o fundo histórico reivindicado em afirmações sobre a existência de um sentimento sedimentado, que alimenta as lutas por uma determinada "causa", apagando a dimensão fundamentalmente efêmera das "paixões" envolvidas na militância em projetos políticos.

Por isso, neste artigo, me pareceu proveitoso realizar uma leitura no marco dos afetos, recuperando seu sentido de afetação (Butler 2015) e chamando atenção para aquilo que "escapa", inclusive ao se tentar capturar estrategicamente um determinado referente afetivo para "fazer uma realidade" (Austin 1975) a serviço de um projeto de mobilização. Assim, pude incorporar na análise a dimensão dos afetos difusos acionados pelas referências à palavra-ato Tapajós, de forma a destacar o modo ativo como meus interlocutores buscaram acionar afetos para "fazer crescer" a mobilização em torno da causa. Ao explorar o universo das reações afetivas primárias associadas ao termo, pude demonstrar como a polissemia da "palavra-ato" Tapajós permitiu mobilizar, de forma exitosa, sentimentos de reconhecimento com as muitas "realidades feitas" pelo termo, garantindo-lhe uma transversalidade e uma potência de afetação e “comunização", (Weber 1999) dimensões que me pareceram fundamentais para compreender a enorme adesão ao projeto em Santarém. Tratei, portanto, de apresentar como os afetos e as afetações podem ser lidos como produtos e produtores da ação política, chamando atenção para como os sentimentos e as emoções são continuamente "enquadrados" (Butler 2015), formatados e capturados por disputas desenroladas na "arena pública" (Cefaï 2009).

Ao longo do artigo, busquei apresentar o tempo descontínuo dos trâmites e das negociações atravessadas pela burocracia estatal; o tempo acelerado da campanha realizada para o evento extraordinário do plebiscito; o tempo profundo da história, que reivindicavam como "prova" da legitimidade de sua luta; e o tempo lento de uma mobilização que desce ao cotidiano, realizada de maneira difusa, através das rádios, da paisagem, das músicas e das palavras, que aos poucos vão se tornando comuns para expressar o lugar em que se nasceu. Nesse sentido, penso 
que o caso apresentado e a atenção aos afetos envolvidos no curso de mobilizações sociais podem suscitar questões a respeito dos tempos em que se fazem as lutas e as "causas". Levar a sério o fundo histórico reivindicado por nossos interlocutores ao narrarem os sentimentos sedimentados que acreditam "legitimar" suas lutas não significa atribuir às histórias relatadas o mesmo estatuto de verdade e perenidade atribuídos pelos militantes, apenas consiste em se permitir seguir as muitas linhas existentes entre processos históricos concretos e processos de produção de mobilizações sociais.

Acredito que essa discussão sobre os referentes afetivos acionados no processo de mobilização pela criação do estado do Tapajós nos coloca questões a respeito da maneira como as particularidades do processo histórico no contexto amazônico atravessam as mobilizações sociais locais. Ao recuperar como a transversalidade do termo Tapajós passava por características do processo de ocupação e colonização da região e pelas especificidades da composição da malha urbana na Amazônia (Castro 2009), busquei indicar como a abordagem desses dados históricos poderia suscitar novas questões para o trato dos potenciais afetos e sentimentos associados a certos termos, explorando como afetações potenciais poderiam ser capturadas para "fazer crescer" mobilizações sociais na região amazônica. Sugiro, portanto, que a atenção às "realidades feitas" e aos sentimentos acionados por determinadas "palavras-ato" (Austin 1975) pode contribuir para um adensamento de discussões a respeito do lugar ocupado por referentes transversais de pertencimento regional (Tapajós, Xingu, oeste do Pará) no processo de produção de adesões aparentemente incompatíveis a projetos políticos pensados para a Amazônia.

\section{AGRADECIMENTOS}

As reflexões apresentadas neste artigo foram resultado de pesquisa de mestrado realizada entre 2014 e 2016, no Programa de Pós-Graduação em Antropologia Social do Museu Nacional (UFRJ), sob orientação de Adriana Vianna, com financiamento de bolsa de estudos oferecida pela Coordenação de Aperfeiçoamento de Pessoal de Nível Superior (CAPES). Uma versão anterior do texto foi apresentada e debatida no Seminário "Lutas no Pará: etnografias de mobilizações sociais”, realizado pelo Núcleo de Antropologia da Política, no Museu Nacional, onde pude contar com as contribuições de Dibe Ayoub, Maria Rossi Idarraga e João Lagüéns, a quem agradeço pelos comentários atenciosos ao trabalho naquela oportunidade. 


\section{REFERÊNCIAS}

Alarcon, D. F., N. R. Guerrero, e M. Torres. 2016. "Saída pelo norte": a articulação de projetos de infraestrutura e rotas logísticas na bacia do Tapajós, in Ocekadi: hidrelétricas, conflitos socioambientais e resistência na bacia do Tapajós. Organizado por B. Milikan e M. Torres, pp. 43-78. Brasília: Internacional Rivers Brasil. Santarém: Programa de Antropologia e Arqueologia da Universidade Federal do Oeste do Pará.

Almeida, L. S. 2013. Gaúchos, festas e negócios: o agronegócio da soja no Meio-norte mato-grossense. Tese de Doutorado, Departamento de Antropologia e Sociologia, Universidade Federal do Rio de Janeiro, Rio de Janeiro.

Austin, J. L. 1975. How to do things with words. London: Oxford University Press.

Bailey, F. G. 1993. The tactical uses of passion: an essay on power, reason and reality. Ithaca and London: Cornell University Press.

Bemerguy, T. S. 2017. Criando Estado, fazendo região: gramáticas em disputa na invenção do Estado do Tapajós. Dissertação de Mestrado, Departamento de Antropologia Social, Universidade Federal do Rio de Janeiro/Museu Nacional, Rio de Janeiro.

Bemerguy, T. S. 2019. (Novas) fronteiras e ideários coloniais de longa duração: uma análise a partir da disputa pela reconfiguração territorial da Amazônia brasileira. Antropolítica (46):188-215.

Bernardes, J. A. B, e O. L. F. Filho (Org.). 2010. Geografias da soja: BR-163, fronteiras em mutação. Rio de Janeiro: Arquimedes Edições.

Boltanski, L. 1990. El amor y la justicia como competencias: tres ensaios da sociologia da acción. Paris: Editión Métailié. 
Boltanski, L., e L. Thévenot. 1999. The sociology of critical capacity. European fournal of Social Theory 2(3):359-377. DOI: https://doi.org/10.1177/136843199002003010.

Bourdieu, P. 1989. A identidade e a representação: elementos para uma reflexão crítica sobre a ideia de região, in O poder simbólico, de P. Bourdieu, pp. 107-132. Rio de Janeiro: Bertrand Brasil.

Bourdieu, P. 1996. É possível um ato desinteressado?, in Razões práticas: sobre a teoria da ação, de P. Bourdieu, pp. 137-156. Campinas, São Paulo: Ed. Papirus.

Brasil. 1988. Constituição Federal. Brasília/DF. Disponível em: http://www.planalto.gov.br/ccivil_03/ constituicao/constituicaocompilado.htm. Acesso em: 10 ago. 2016.

Brasil. 1990. Constituinte. Comissão de Estudos Territoriais. Relatório n ${ }^{\circ} 01$, de 1990: sobre o território nacional e anteprojetos relativos à novas unidades territoriais, notadamente na Amazônia Legal e em áreas pendentes de solução. Relator: Deputado Gabriel Guerreiro. In: BRASIL. Câmara dos Deputados. Disponível entre as matérias relacionadas ao Substitutivo da Câmara dos Deputados ao Projeto de Decreto Legislativo no 19, de 1999 que convoca plebiscito sobre a criação do Estado do Tapajós. Relator: Vital do Rego. Tramitação encerrada. Disponível em: https://www25.senado.leg.br/web/atividade/materias/-/materia/100176?o=t. Acesso em 10 ago. 2016.

Brasil. 1998. Presidência da República. Casa Civil. Subchefia para Assuntos jurídicos. Lei nº 9709, de 18 de novembro de 1998. Regulamenta a execução do disposto nos incisos I, II e III do art. 14 da Constituição Federal. Artigo $3^{\circ}$ : sobre as regras para convocação de plebiscitos e referendos que tratem de questões de relevância nacional. Disponível em: http://www.planalto.gov.br/ccivil_03/leis/19709. htm. Acesso em: 10 ago. 2016.

Brasil. 1999. Senado Federal. Projeto de decreto legislativo no 19 de 1999: convoca plebiscito sobre a criação do Estado do Tapajós. Autoria: Senador Mozarildo Cavalcanti. Relator: Romeu Tuma. Data de leitura: 02 de março de 1999. Tramitação encerrada. Disponível em: https://www25.senado.leg.br/ web/atividade/materias/-/materia/608. Acesso em 10 ago. 2016. 
Brasil. 2011. Câmara dos Deputados. Substitutivo da Câmara dos Deputados ao Projeto de Decreto Legislativo $n^{\circ}$ 19, de 1999: convoca plebiscito sobre a criação do Estado do Tapajós. Autoria: Câmara dos Deputados. Relator: Vital do Rego. Data da leitura: 11 de maio de 2011. Tramitação encerrada. Disponível em: https://www25.senado.leg.br/web/atividade/materias/-/materia/100176?o=t. Acesso em 10 de ago 2016.

Brasil. 2016. Senado Federal. Artigo 101: Sobre as competências da Comissão de Constituição e Justiça, in Regimento Interno do Senado Federal. Brasília.

Butler, J. 2015. Quadros de guerra: quando a vida é passível de luto? Rio de Janeiro: Civilização Brasileira.

Castilho, S. R., A. C. Souza Lima, e C. Costa Teixeira. 2017. Antropologia das práticas de poder: reflexões etnográficas entre burocratas, elites e corporações. Rio de Janeiro: Contra Capa.

Castro, E. M. R (org). 2008a. Sociedade, território e conflitos: BR-163 em questão. Belém: NAEA/UFPA.

Castro, E. M. R. 2009. Urbanização, pluralidade e singularidades das cidades amazônicas, in Cidades na floresta. Organizado por E. Castro, pp. 13-39. São Paulo: Annablume.

Castro, M. C. A. 2008b. Mobilização do trabalho na Amazônia. O oeste do Pará entre grilos, latifúndios, cobiças e tensões. Tese de Doutorado, Departamento de Geografia, Universidade de São Paulo, São Paulo.

Cefaï, D. 2009. Como nos mobilizamos? A contribuição de uma abordagem pragmatista para a sociologia da ação coletiva. Dilemas-Revista de Estudos de Conflito e Controle Social 2(4):11-48.

Coimbra, H. 1993. Estado do Tapajós: uma opção para o desenvolvimento da Amazônia. Brasília: Câmara dos Deputados.

Coimbra, H. 1997. Estudo de viabilidade econômica do Estado do Tapajós. Brasília: Câmara dos Deputados. 
Corrêa, D. S., e R. D. C. Dias. 2016. A crítica e os momentos críticos: de la justification e a guinada pragmática na sociologia francesa. Mana 22(1):67-99. DOI: http://dx.doi.org/10.1590/0104-93132016v22n1p067.

Costa, M. V. V. 2012a. BR-163 paraense: caminho para o desenvolvimento ou para a exclusão? Dissertação de Mestrado, Departamento de Geografia, Universidade Federal do Rio de Janeiro, Rio de Janeiro.

Costa, S. H. G. 2012b. A questão agrária no Brasil e a bancada ruralista no Congresso Nacional. Tese de doutorado, Departamento de Geografia, Universidade de São Paulo, BR.

Costa, C., e P. Pacheco. 2011. Fundamentos para a criação do Estado do Tapajós: efetivando a presença do Estado na Amazônia Brasileira. Santarém: Impresso pelo autor.

Dutra, M. 1999. O Pará dividido: discurso e construção do Estado do Tapajós. Belém: UFPA/NAEA.

Fonseca, W. D. 1990. Santarém: momentos históricos. Santarém: Editora Tiagão.

Foucault, M. 2010. A arqueologia do saber. Rio de Janeiro: Forense Universitária.

Goodwin, J., J. M. Jasper, e F. Polletta. 2001. Introduction: why emotions matter, in Passionate politics: emotions and social movements. Organizado por J. Goodwin, J. M. Jasper, e F. Polletta. Chicago: University of Chicago Press.

Guianet. 2016. Mapas do Brasil/Mapa do Pará. Disponível em: https://guianet.com.br/links/externos/ mapa/103-para-pa. Acesso em: 10 ago. 2016.

Heredia, B., e M. Palmeira. 1995. Os comícios e a política de facções. Anuário Antropológico 94:31-94.

Hobsbawm, E., e T. Ranger. 2002. A invenção das tradições. Rio de Janeiro: Paz e Terra. 
Instituto de Desenvolvimento Econômico, Social e Ambiental do Pará (IDESP). 2011. Estado do Pará: (di)visões territoriais, perspectivas sociais, econômicas, financeiras e ambientais. Belém: IDESP.

Madariaga, A., e C. Galleguillos. 2013. Sobre Sociología, crítica y emancipación: entrevista con Luc Boltanski. Revista Némesis 10:137-146.

Nader, L. 1972. Up the anthropologist: perspectives gained from studying up. Berkeley: University of California.

Pró-Tapajós, A.P. 2011. Setenta e sete razões para a criação do Estado do Tapajós, in Rede Mocoronga, por F. Pena. Disponível em: http://redemocoronga.org.br/2011/09/setenta-e-sete-razoes-para-a-criacaodo-estado-do-tapajos/. Acesso em: 10 ago. 2016.

Pró-oeste, M. e M. Pró-criação do estado do Tapajós. Estudo de viabilidade econômica do Estado do Tapajós. Santarém: Tiagão, 1996.

Reis, A.C. F. 1979. Santarém: seu desenvolvimento histórico. Rio de Janeiro: Civilização Brasileira.

Torres, M. (Org.). 2005. Amazônia revelada: os descaminhos ao longo da BR-163. Brasília: CNPQ.

Vianna, A., e J. Farias. 2011. A guerra das mães: dor e política em situações de violência institucional. Cadernos Pagu (37):79-116. DOI: http://dx.doi.org/10.1590/S0104-83332011000200004.

Vianna, A. 2014. Violência, Estado e Gênero: considerações sobre corpos e corpus entrecruzados, in Margens da violência. Subsídios ao estudo do problema da violência nos contextos mexicanos e brasileiros. Organizado por A. C. Souza Lima e V. Garcia-Acosta, pp.209-237. Brasília: ABA.

Weber, M. 1999. Comunidades étnicas, in Economia e sociedade: fundamentos da sociologia compreensiva, de M. Weber, pp.315-327. Brasília: UnB. 